\title{
Ayurved-A Divine Boon to Geriatrics-A Critical Review
}

\author{
Dr. Shivani Sanjeev Gavande ${ }^{1}$, Dr. J. J. Magdum², Dr. Anil B. Chandanshive ${ }^{3}$ \\ ${ }^{1}$ M.D (Ayu), Ph.D (Scholar), Associate Professor in Kayachikitsa \\ ${ }^{2}$ Ayurved Medical College, Jaysingpur \\ ${ }^{3}$ M.D.(Ayu.), Assistant Professor in Shareer Kriya
}

\begin{abstract}
Advancement in medical sciences has prolonged the life of human beings. But there is no positive assurance of healthy sound life from modern advancements. Geriatric population is increasing day by day. Growth rate of older population is faster than that of total population. It is more in developing countries than developed countries. In India, it will be 12\% in 2025. In geriatric population, nutritional deficiencies, epidemiological problems. microbiological diseases, psychological diseases are very common. Ayurved can give these people an assuring solution. Dinacharya, Rutucharya, Aachaar Rasayan can help the elder ones to live their life happily.
\end{abstract}

Keywords: Ayurved, Geriatrics, Senile debility, Rutucharya, Dincharya. Rehabilitation

\section{Introduction}

कालस्य परिणामेन जरामृत्युनिमित्तजः

रोगाः स्वाभाविकाः दृष्टवा स्वभावो निष्प्रतिक्रिया || च.शा.१/१ १४

Senile stage of life and death both are called Natural Diseases as they give grief(दु:ख) to humans and has no remedy.

\section{सप्ततेरूहर्व}

धात्वीन्द्रीयबलवीर्योत्त्साहमहन्यहनिवलीपलित कासश्वासप्रभृति निरुपद्रवेंभिरविभूपमानं जीर्णागारमिवाभिवाभिवृष्टमवसीदनते वृद्धमाचक्षते |सु.सू. २५/२६

After 70 years, catabolic processes are more, resulting wrinkles on skin, loe peach voice. anorexia, dry cough, weight loss and constipation

\section{Aims and Objects}

1) To enhance heath status of body and mind of Geriatric group of people.

2) To give the best possible preventive measures for disabled and diseased old generation.

\section{Materials and Methods}

जराशोषो कृशो मन्दवीर्यबुधिद बलेन्द्रीयः

कम्पनोरुचिमान् भिन्नकांस्यपात्रहतः स्वरः ॥

प्ठीवति श्लेष्मणा हीनं गौरवारुचिपीडितः।

सप्रसृतास्य नासाऽक्ष शुष्क रूक्ष मलाछविः ॥

In old age, person becomes slim weak. Tremors especially in hands, neck and legs make him insecure. There is loss of memory, strength of body and mind also. Luster of skin disappears and it becomes wrinkled. Dry cough irritates him Secretions come from mouth, nose and eyes. Excreta also become dry.
Ayurved is science of life. Dinacharya is a regimen to be followed daily. Rutucharya is to be followed with changing seasons.

If any person follows such simple rules since childhood, then he can keep away the senile debility.

Awakening: Early to bed, early to rise make us healthy and wise. One should get up one hour before sunrise. In old age, due to changes in physiology, person suffers from insomnia. But simple til oil application on naval region at night can solve this problem

Brushing: Danta dhavan is the procedure to keep oral hygiene healthy. Massaging to gums and teeth with bitter tasted Nimb stick keeps gum and teeth strong. gandush and Kaval vidhi are the procedures to keep total oral cavity healthy.

Defecation: Defecation at early morning is best practice to remove unwanted material from body. As day goes on, there is reabsorption of toxic material in body which can creat disease. We should obey our natural urges.

Exercise: Suitable exercise with proper guidance is advisable in old age. Yogasanas, Suryanamaskaar, Pranayaam retains the energy level and mascular strength also.

Criteria of enough exercise for each individual differ from person to person. When there is sweating in the axilla and on forehead, you should stop exercise.

Bathing techniques: In old age, one must do oil massage and then udvartan (powder massage) to get the luster and intact skin.

Food: Limited nutritious food must be consumed in old age. Food not only nourishes the body but nourishes mind also. So healthy freshly prepared diet with proper amount of liquids should be taken. Even the mentality of cook also has 


\section{International Journal of Science and Research (IJSR) \\ ISSN (Online): 2319-7064}

Index Copernicus Value (2015): 78.96 | Impact Factor (2015): 6.391

influence on food. Ayurved gives equal importance to that also.

Sleep: Seven to eight hours sleep at night is essential to keep our health. Person above 80 years can take daytime sleep in the afternoon for two hours. For rehabilitation physiotherapist, Yoga teacher, speech therapist, psychiatric councillers, Panchakarma specialist and dietician can play a vital role

\section{Discussion}

Following Dincharya can improve the health status of a person.

- Prevention is better than cure.

- Mind set up of elder ones should be positive and little flexible, so that he can positively accept the changes in old age.

\section{Conclusion}

Geriatric medicine has become much more important mow a days. If a person follows Ayurvedic system in his day to day activity, he can enjoy his prolonged healthy life happily.

\section{References}

[1] Charak Samhita Chakrapaani commentary Rasayan Chikitsa Adhyaay.

[2] API MEDICINE

[3] Sushrut Samhita nibandhsangrah Vyakhya commentary. 